\section{With Rachlis abandon}

Prescription for excellence: how innovation is saving Canada's health care system

Michael Rachlis

Toronto: HarperCollins; 2004

418 pp. \$32.95 ISBN 0-00-200661-8

$\mathrm{T}$ he title of this book declares that the book contains "a prescription for excellence," and its subtitle promises to show us "how innovation is saving Canada's health care system." The deliverer of these reassuring themes is Michael Rachlis, who is a busybody of a thinker: a confirmed optimist who knows how to complain, and someone who cares deeply about Canadian medicare. This book reflects all these happy sides of him. In it, he has collected a multitude of stories that are clear examples of where medicare does work and where it doesn't. He has also collected especially good examples of instances where things have been made better in a health care system that is under considerable pressure. At the end of each chapter, Rachlis includes a series of questions that citizens can use to find out how their bit of the health care system is working. These questions point toward initiatives that can be used to make the system more responsive to our needs.

The numerous stories, delivered with journalistic panache and in the best tradition of the Rachlis anecdote, are a treat. When he is close to the material his stories are sharp, realistic and insightful. At times, however, he strays from his own patch, and when he goes far enough afield his stories begin to stretch the truth ever so slightly, either to confirm the author's optimism about those parts of our health care system that he loves, or to justify his negative reaction to the things that worry him. With an eye toward the optimistic, Rachlis idealizes the CLSCs (primary care and social service centres) in Quebec a bit too much (although, despite their blemishes, they are in the vanguard of efforts to expand primary care). In Quebec, this move toward primary care is called virage ambulatoire, but, given the

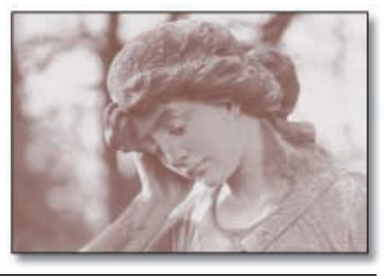

many shortcomings of the CLSCs and the continuing emphasis on the acutecare sector, it is often considered a $m i-$ rage ambulatoire.

On the negative side, Rachlis goes a bit overboard when he vilifies the level of adverse events in hospitals. If, as he says, the levels are equivalent in Canada, the United States and the United Kingdom, then it may be that all this very expensive research has done is to discover a common baseline for adverse events that is not a quality issue, but rather a characteristic of complex hospital systems. Similar studies on automobile safety have not resulted in a reduced rate of accidents, but have established the baseline for the number of accidents that might occur for so many driver miles.

I see two main arguments at the basis of this book. First, it is argued that the Canadian system can and should be saved from the perils of privatization. This can be accomplished if we begin by stabilizing what has become a somewhat destabilized system. Some steps should be taken to regularize doctors' incomes and make their earnings more equitable; to provide nurses and other health care workers with more secure employment and better work environments; and to stabilize funding for the system and increase funding for those parts of it that have been neglected, such as primary and long-term care. Once the system settles down, then it would be a mat- ter of taking some of the much smaller pieces of innovation - ideas that are already working in Canada, the US and the UK - and using them to make the system better.

Behind these arguments and prescriptions there appears to be a growing awareness by Rachlis that medicare functions much like other complex adaptive systems. He agrees that change in the system requires a certain degree of stability, that fixing the system must largely be done by means of relatively small and local efforts, and that the participants in the system including citizens and health care workers themselves - must be enabled to take the lead in these efforts. Despite lots of flurries in many different directions, slight exaggerations and a number of unnecessary paths, this is a very good and interesting overview of the present state of the complex Canadian health care system, told with passion and insight.

\section{Sholom Glouberman}

Philosopher in Residence

Baycrest Centre for Geriatric Care Toronto, Ont.

\section{Models of composure}

Things cannot always go your way. Learn to accept in silence the minor aggravations ... - - William Osler, 1903

Should equanimity be so widely praised for all physicians? - Howard Spiro, 1992

Our virtues are most frequently but vices in disguise. — François, Duc de la Rochfoucauld

Do we move too placidly amid the noise and haste? Do we know how to put anger to good use? Tell us about the times you've made a fuss, and - just maybe - improved things a little. We welcome submissions of unpublished poetry, memoir and fiction for The Left Atrium. The writing should be candid, but patient confidentiality must be respected. A sense of humour never hurts. In general, prose manuscripts should be limited to 1000 words and poems to 75 lines. Vent your spleen: at annemarie.todkill @cma.ca 